\title{
Magnesium butyrate is a readily available magnesium source in dairy cow nutrition
}

\author{
Bastiaan M. de Groot ${ }^{1}$, Joan E. Edwards ${ }^{2}$ and J. Thomas Schonewille ${ }^{1, *}$ \\ 1 Department of Public Health Sciences, Utrecht University, Yalelaan 112, 3584 CM, Utrecht, Netherlands; \\ b.m.degroot96@gmail.com (B.M.G.), j.t.schonewille@uu.nl (J.T.S.) \\ 2 Palital Feed Additives, De Tweede Geerden 11, 5331 XE, Velddriel, Netherlands; j.edwards@palital.com \\ * Correspondence: j.t.schonewille@uu.nl
}

Simple Summary: An adequate supply of magnesium is considered of great interest to prevent milk fever and grass tetany in dairy cows. Currently, magnesium oxide $(\mathrm{MgO})$ is widely used to supplement dairy cows with magnesium. In dry cow nutrition, however, magnesium butyrate can be considered of interest as an alternative source of supplemental magnesium. This is because the use of magnesium butyrate, instead of $\mathrm{MgO}$, is potentially advantageous because butyrate, but not oxide, may stimulate the growth of rumen papillae which is instrumental to prevent rumen acidosis. However, the bioavailability of magnesium from magnesium butyrate is not known. Therefore, an experiment was conducted with dairy cows to determine this. Six dairy cows were fed rations with or without magnesium butyrate supplementation, and feces was collected in order to enable magnesium absorption to be determined. The results showed that magnesium from magnesium butyrate was readily available for absorption. Using previously published data, magnesium butyrate was also indicated to be a superior source of magnesium relative to $\mathrm{MgO}$. In conclusion, this study indicates that magnesium butyrate can be considered as an attractive alternative magnesium source to supplement dairy rations with magnesium.

\begin{abstract}
The aim of the present study was to measure the apparent absorption of magnesium (Mg) originating from Mg-butyrate. Six mid-lactation Holstein Friesian dairy cows were used with dietary treatments arranged in a cross-over design. Two different diets were fed during the experiment, consisting of a low $\mathrm{Mg}$ diet without $\mathrm{Mg}$-butyrate ( $\mathrm{L}-\mathrm{Mg}$, $3.1 \mathrm{~g} \mathrm{Mg} / \mathrm{kg}$ dry matter) or a high $\mathrm{Mg}$ diet with $\mathrm{Mg}$-butyrate (H-Mg, $3.9 \mathrm{~g} \mathrm{Mg} / \mathrm{kg}$ dry matter). Cows offered the L-Mg diet ingested $54.7 \mathrm{~g}$ $\mathrm{Mg} /$ day while the cows fed the $\mathrm{H}-\mathrm{Mg}$ diets ingested $66.3 \mathrm{~g} \mathrm{Mg} /$ day $(P<0.001)$. The fecal excretion of $\mathrm{Mg}$, however, was similar between the two experimental diets $(P=0.174)$. Consequently, apparent $\mathrm{Mg}$ absorption was found to be 7.9 percentage units greater $(P=0.038)$ when the cows were fed the diet supplemented with $\mathrm{Mg}$-butyrate. The greater $\mathrm{Mg}$ absorption after feeding the $\mathrm{H}-\mathrm{Mg}$ diet was, however, not reflected by a greater urinary $\mathrm{Mg}$ concentration $(P=0.228)$. These results indicate that the availability of $\mathrm{Mg}$ from the $\mathrm{Mg}$-butyrate supplemented diet is high ( $34.1 \%$ of intake). The fractional $\mathrm{Mg}$ absorption from $\mathrm{Mg}$-butyrate was calculated to be $71.6 \%$. In conclusion, $\mathrm{Mg}$-butyrate is an attractive alternative to supplement dairy rations with $\mathrm{Mg}$.
\end{abstract}

Keywords: magnesium; absorption; rumen; butyrate; volatile fatty acids

\section{Introduction}

Magnesium (Mg) is an essential nutrient for cows. This means that dairy rations need to supply a sufficient amount of absorbable $\mathrm{Mg}$ to safeguard the cow's health. Currently, there is no experimental proof for any specific $\mathrm{Mg}$ regulating hormone [1]. This implies that $\mathrm{Mg}$ intake as such does not downregulate the efficiency of $\mathrm{Mg}$ absorption. Consequently, the amount of absorbed $\mathrm{Mg}$ in excess of requirement is excreted in the urine in order to maintain $\mathrm{Mg}$ balance. The efficiency of $\mathrm{Mg}$ absorption is considered the critical determinant in the $\mathrm{Mg}$ supply of dairy cows [2]. The amount of $\mathrm{Mg}$ that is available for metabolism depends on both the amount and source of $\mathrm{Mg}$ ingested by the animals, however, it is also dependent on the content of dietary potassium $(\mathrm{K})$. It is well known that $\mathrm{K}$ 
inhibits $\mathrm{Mg}$ absorption in the rumen of the cow [3]. This increases the risk of hypomagnesemia [4], and subsequently grass tetany or milk fever [5].

In many countries, grass and its co-products are usually rich in K. Consequently, it is common practice in such countries to supplement dairy rations with $\mathrm{Mg}$. Magnesiumoxide $(\mathrm{MgO})$ is currently widely used as a source of supplemental $\mathrm{Mg}$. The effectiveness of $\mathrm{MgO}$ in terms of supplying $\mathrm{Mg}$, however, is limited [6] and can vary greatly between different $\mathrm{MgO}$ sources [7,8]. As a consequence alternative $\mathrm{Mg}$ sources, such as Mg-butyrate, might be of interest.

Currently, supplemental butyrate has gained interest for ruminants in both practice and research. This interest is related to the evidence that butyrate is a main stimulator of papillae growth and epithelial cell proliferation in the rumen $[9,10]$. By increasing the size of rumen papillae, and thus the rumen surface area, absorption of short chain fatty acids is enhanced. This enhanced absorption increases the buffer capacity of the rumen content, leading to lower susceptibility to rumen acidosis [11]. In other words, supplemental butyrate may be instrumental in preparing the cow to adapt to high concentrate rations $[12,13]$. From this perspective, $\mathrm{Mg}$ supplementation in the form of Mg-butyrate can be considered opportune to use in the nutrition of dry cows. Thus, the use of Mg-butyrate instead of $\mathrm{MgO}$ seems an attractive alternative to supplement dairy rations with $\mathrm{Mg}$. However, the availability of $\mathrm{Mg}$ from Mg-butyrate is not known. The aim of the current experiment was, therefore, to measure the apparent $\mathrm{Mg}$ absorption when $\mathrm{Mg}$-butyrate is used as the Mg source.

\section{Materials and Methods}

\subsection{Experimental Design}

Six, multiparous, mid-lactation cows (approx. 120 days in milk) producing around $30 \mathrm{~kg}$ of milk per day were used in the experiment. The experiment was designed as a cross-over with 2 experimental periods of 14 days each, preceded by a 14 day pre-experimental period to allow the cows to become adapted to the experimental rations. The cows were individually fed in a stanchion barn with unrestricted access to fresh water.

\subsection{Experimental Rations}

During the pre-experimental period all six cows were fed a basal ration (Table 1) supplemented with $2.7 \mathrm{~kg}$ dry matter (DM) commercial compound feed and $1.8 \mathrm{~kg}$ DM low sugar beet pulp without any additives. During the experimental periods, the beet pulp was replaced by experimental beet pulp i.e., beet pulp with or without supplemented Mg-butyrate (Rumen-Ready®, Palital Feed Additives, Velddriel, The Netherlands), i.e., high $\mathrm{Mg}$ and low Mg beet pulp, respectively (Table 1). The supplemental Mg-butyrate used, Rumen-Ready ${ }^{\circledR}$, was in the form of a micro pellet with a diameter of $\sim 1.2 \mathrm{~mm}$ and consists of (as fed) 70\% Mg-butyrate encapsulated in a fat matrix. The Mg-butyrate from Rumen-Ready ${ }^{\circledR}$ is completely released and solubilized within the rumen, i.e., it is $100 \%$ available for absorption. Both types of experimental beet pulp contained titanium oxide $\left(\mathrm{TiO}_{2}\right)$, which was used as an inert marker for determination of fecal output. The cows were randomly assigned to the order of the two experimental treatments.

\subsection{Feeding Procedure}

At 9:00 $\mathrm{h}$ the daily individual feed refusals, if any, were collected. These were then weighed and stored at $-18{ }^{\circ} \mathrm{C}$. The rations were offered twice daily in two equal portions starting at $\sim 9: 15 \mathrm{~h}$ and $\sim 16: 30 \mathrm{~h}$. At each feeding time, cows were first offered their allocated amounts of compound feed and beet pulp and then 30 min later, half of the daily portion of the basal ration was offered (Table 1). 
Table 1. Ingredients and calculated chemical composition of the experimental rations.

\begin{tabular}{cc}
\hline \multirow{2}{*}{ Parameters } & \multicolumn{2}{c}{ Treatment } \\
\cline { 2 - 2 } & Low Mg High Mg \\
\hline
\end{tabular}

Ingredient composition (kg DM):

Basal ration $^{1}$

Compound feed

Experimental beet pulp

Low $\mathrm{Mg}^{2}$

High $\mathrm{Mg}^{3}$

Total (kg DM)

Calculated composition of the whole experimental ration

$$
\begin{aligned}
& \mathrm{NEL}, \mathrm{MJ} / \mathrm{kg} \mathrm{DM} \\
& \mathrm{Mg}, \mathrm{g} / \mathrm{kg} \mathrm{DM} \\
& \mathrm{K}, \mathrm{g} / \mathrm{kg} \mathrm{DM} \\
& \mathrm{Ca}, \mathrm{g} / \mathrm{kg} \mathrm{DM} \\
& \mathrm{P}, \mathrm{g} / \mathrm{kg} \mathrm{DM}
\end{aligned}
$$

18.1
18.1

6.91

3.9

23.7

6.0

3.3

\footnotetext{
${ }^{1}$ Basal ration consisted of (\% DM): grass silage, 67.0 ; corn silage, 26.5 ; bypass soybean meal, 5.9; mineral premix, 0.7 .

${ }^{2}$ Low Mg beet pulp; pellet containing 99.2\% low sugar beet pulp and $0.8 \% \mathrm{TiO}_{2}$

${ }^{3} \mathrm{High} \mathrm{Mg}$ beet pulp; pellet containing $91.7 \%$ low sugar beet pulp, $0.8 \% \mathrm{TiO}_{2}$ and $7.5 \%$ RumenReady®
}

\subsection{Sampling Procedure and Chemical Analysis}

During the last 4 days of each $14 \mathrm{~d}$ experimental period, all spontaneously voided feces and urine were collected between 9:00 and 17:00. At the end of each collection day, the individual feces collections were stored at $-18{ }^{\circ} \mathrm{C}$ whereas the individual urine collections were stored at $5{ }^{\circ} \mathrm{C}$. At the end of each experimental period, the individual feces collections were thawed. Then, all individual feces and urine collections were pooled per cow and mixed thoroughly. Thereafter, the pooled fecal and urine samples were stored at $-18^{\circ} \mathrm{C}$ pending chemical analysis. All samples were air dried at $60^{\circ} \mathrm{C}$ for $24 \mathrm{~h}$ and the dry matter (DM) content of the air-dried samples was determined with the use of a forced-air oven $\left(105^{\circ} \mathrm{C}, 24 \mathrm{~h}\right)$ according to ISO standards [14]. The $\mathrm{Mg}$ content of feces, urine, feed and feed refusals was measured by means of inductively coupled plasma mass spectrometry. The titanium concentration of the experimental beet pulp and feces was analyzed according to the method of Myers et al. [15] with modifications. Ti was determined using a spectrophotometer (Beckman Coulter Inc., Brea, USA) equipped with sipper module for $408 \mathrm{~nm}$ instead of $410 \mathrm{~nm}$ as reported by Myers et al. [15].

\subsection{Statistical Analysis}

All data were subjected to analysis of variance with the general linear model procedure in SPSS, using the model:

$$
Y i j=\mu+P E R I O D i+\text { TREATMENT } j+e i j
$$

where $\mathrm{Yij}_{\mathrm{ij}}=\mathrm{a}$ response variable (e.g., $\mathrm{Mg}$ intake, fecal Mg excretion, etc.); $\mu=$ overall mean; PERIODi $=$ experimental period $(i=1$ or 2$)$; TREATMENT $j=$ level of dietary magnesium ( $\mathrm{j}=$ low or high); and eij = residual error. Both, the PERIOD and TREATMENT were set as fixed factors in the statistical model. Throughout, the level of statistical significance was pre-set at $P \leq 0.05$. 


\section{Results}

\subsection{Feed Intake and Milk Yield}

The amount of DM offered was not fully consumed by the cows and the mean amounts of DM refused were $1.1 \mathrm{~kg}$ DM and $0.7 \mathrm{~kg}$ DM for the cows fed the high- and low $\mathrm{Mg}$ rations, respectively. Consequently, DM intakes were found to be $16.9 \mathrm{~kg}$ (SE \pm $0.51)$ and $17.4 \mathrm{~kg}(\mathrm{SE} \pm 0.43)$ for high- and low $\mathrm{Mg}$ treatment groups $(P=0.543)$, respectively. The mean milk production was similar $(P=0.836)$ between the two treatments, i.e. $26.5 \mathrm{~kg} /$ day $(\mathrm{SE} \pm 2.39)$ and $27.2 \mathrm{~kg} /$ day $(\mathrm{SE} \pm 2.04)$ for the high- and low $\mathrm{Mg}$ treatments, respectively.

\section{2. $\mathrm{Mg}$ Absorption and Urinary $\mathrm{Mg}$ Concentration}

The intake of $\mathrm{Mg}$ increased $(P<0.001)$ from $54.7 \mathrm{~g} /$ day to $66.3 \mathrm{~g} /$ day when the cows were fed the high- instead of the low $\mathrm{Mg}$ ration (Table 2). However, fecal Mg excretion was found to be similar $(P=0.174)$ between the two experimental rations. Consequently, Mg absorption, either expressed as g/day or as a \% of intake, were greater $(P \leq 0.038)$ when the high $\mathrm{Mg}$ ration was fed. The urinary $\mathrm{Mg}$ concentration in the animals fed the low $\mathrm{Mg}$ ration (Mean, $10.6 \mathrm{mmol} / \mathrm{L}$, Standard Error (SE) 1.81) and high $\mathrm{Mg}$ ration $(13.9 \mathrm{mmol} / \mathrm{L}$, SE 1.80) was found to be similar $(P=0.228)$.

Table 2. Mg intake, fecal Mg excretion and $\mathrm{Mg}$ absorption in cows fed the experimental rations with or without $\mathrm{Mg}$-butyrate supplementation (i.e., high and low $\mathrm{Mg}$, respectively).

\begin{tabular}{lcccc}
\hline \multicolumn{1}{c}{ Parameter } & Low $\mathbf{M g}$ & High $\mathbf{M g}$ & SEM & $\boldsymbol{P}$ value \\
\hline & & & & \\
Mg intake, g/day & 54.7 & 66.3 & 1.40 & $<0.001$ \\
$\begin{array}{l}\text { Fecal Mg excretion, g/day } \\
\text { Apparent Mg absorption }\end{array}$ & 40.4 & 43.7 & 1.58 & 0.174 \\
$\quad$ & & & & \\
$\quad$ g/day & 14.3 & 22.6 & 1.66 & 0.006 \\
$\quad \%$ of intake & 26.2 & 34.1 & 2.30 & 0.038
\end{tabular}

\section{Discussion}

In the current study, the amount of absorbed $\mathrm{Mg}$ was found to be $14.3 \mathrm{~g} / \mathrm{day}$ when the low $\mathrm{Mg}$ ration, containing $23.7 \mathrm{~g} \mathrm{~K} / \mathrm{kg} \mathrm{DM}$, was fed. The value on $\mathrm{Mg}$ absorption observed in the current study is $13.4 \%$ greater than predicted based on the regression formula reported by Schonewille et al. [16], i.e., $\mathrm{Mg}$ absorption (g/day) $=3.6+0.2 \times \mathrm{Mg}$ intake (g/day) $-0.08 \times$ Dietary K (g/kg DM). Thus, when the low Mg ration was fed, absolute $\mathrm{Mg}$ absorption (g/day) was more or less in line with expectation. When the cows were fed the ration supplemented with Mg-butyrate, predicted $\mathrm{Mg}$ absorption [16] was calculated to be $15.0 \mathrm{~g} /$ day but observed $\mathrm{Mg}$ absorption was found to be $\sim 1.5$ times greater than predicted (Schonewille et al., 2008). This indicates that $\mathrm{Mg}$ from $\mathrm{Mg}$-butyrate is readily available for absorption. Indeed, the absolute difference in $\mathrm{Mg}$ absorption ( $\Delta \mathrm{Mg}$ absorption) between the current low- and high $\mathrm{Mg}$ diet was $8.3 \mathrm{~g} /$ day while the absolute difference in $\mathrm{Mg}$ intake between the diets ( $\triangle \mathrm{Mg}$ intake) was $11.6 \mathrm{~g} /$ day. Thus, the fractional Mg absorption from $\mathrm{Mg}$-butyrate was calculated to be $71.6 \%$ (i.e., calculated as $\Delta \mathrm{Mg}$ absorption / $\Delta \mathrm{Mg}$ intake $\times 100 \%$ ). The calculated fractional $\mathrm{Mg}$ absorption from $\mathrm{Mg}$-butyrate is much greater compared to the likewise derived values on the fractional $\mathrm{Mg}$ absorption from $\mathrm{MgO}$ (Table 3). Thus, it appears that $\mathrm{Mg}$-butyrate, relative to $\mathrm{MgO}$, is superior in rendering $\mathrm{Mg}$ available for absorption. 
Table 3. $\mathrm{Mg}$ intake, $\mathrm{Mg}$ absorption, $\Delta \mathrm{Mg}$ intake, $\Delta \mathrm{Mg}$ absorption in cows fed increasing amounts of $\mathrm{Mg}$ in the form of $\mathrm{MgO}$ [6].

\begin{tabular}{ccccccc}
\hline Ration $_{i}$ & $\begin{array}{c}\text { Mg intake } \\
\text { (g/day) }\end{array}$ & $\begin{array}{c}\text { Mg absorption } \\
\text { (g/day) }\end{array}$ & $\begin{array}{c}\Delta \text { Mg intake }^{1} \\
\text { (g/day) }\end{array}$ & \multicolumn{2}{c}{$\Delta$ Mg absorption } \\
\cline { 6 - 7 } & & & & & \\
\hline & & & & & & \\
14 & 27.1 & 3.4 & & - & - & - \\
2 & 44.6 & 7.0 & 17.5 & 3.6 & 20.6 \\
3 & 64.6 & 11.9 & 20.0 & 4.9 & 24.5 \\
4 & 83.5 & 17.1 & 18.9 & 5.2 & 27.5 \\
5 & 100.4 & 20.2 & 16.9 & 3.1 & 18.3 \\
6 & 124.3 & 22.0 & 23.9 & 1.8 & 7.5
\end{tabular}

${ }^{1} \Delta \mathrm{Mg}$ intake is calculated as the difference in $\mathrm{Mg}$ intake between ration ${ }^{i+1}$ and ration $i$. For example, the difference in $\mathrm{Mg}$ intake between ration 2 and ration $1=44.6-27.1=17.5 \mathrm{~g}$ $\mathrm{Mg} /$ day.

${ }^{2} \Delta \mathrm{Mg}$ absorption ( $\mathrm{g} /$ day) is calculated as the difference in $\mathrm{Mg}$ absorption between ration ${ }_{i+1}$ and rationi. For example, the difference in $\mathrm{Mg}$ absorption between ration 2 and ration $1=$ $7.0-3.4=3.6 \mathrm{~g} \mathrm{Mg} /$ day

${ }^{3} \Delta \mathrm{Mg}$ absorption expressed as \% of intake is the percentage absorption of $\Delta \mathrm{Mg}$ intake, i.e. ( $\Delta \mathrm{Mg}$ absorption $/ \Delta \mathrm{Mg}$ intake) $\times 100 \%$.

${ }^{4}$ Ration 1 is the control ration, not supplemented with $\mathrm{MgO}$.

For obvious reasons, the current study does not provide clues to explain the difference in $\mathrm{Mg}$ absorption between $\mathrm{Mg}$-butyrate and $\mathrm{MgO}$, but it is well known that the particle size of $\mathrm{MgO}$ is of critical importance for proper solubilization of $\mathrm{MgO}$. Results from various studies $[7,8,17]$ have clearly indicated that the solubility of $\mathrm{MgO}$ is inversely related with its particle size. However, the data presented in Table 3 from Jittakhot et al. [6] is based on a highly soluble $\mathrm{MgO}$ source [7]. Thus, the difference in fractional $\mathrm{Mg}$ absorption between $\mathrm{Mg}$-butyrate and $\mathrm{MgO}$ is difficult to explain by a difference in particle size. It is speculated that, the greater $\mathrm{Mg}$ absorption from $\mathrm{Mg}$-butyrate versus $\mathrm{MgO}$ may be related to the anion moiety of the $\mathrm{Mg}$-butyrate.

To the best of the authors' knowledge, there are currently no published data reporting on the availability of $\mathrm{Mg}$ from Mg-butyrate. However, Ross et al. [18] reported that supplemental $\mathrm{Mg}$ in the form of either calcined magnesite or Mg-acetate prevented hypomagnesemia in grazing cows. Unfortunately, $\mathrm{Mg}$ intakes were not kept constant between supplemental $\mathrm{Mg}$ sources and $\mathrm{Mg}$ absorption was not measured in the Ross et al. [18] study, thereby hindering proper interpretation of the data. Interestingly, Giduck and Fontenot [19] reported on the stimulatory effect of readily fermentable carbohydrates on $\mathrm{Mg}$ absorption in sheep. This observation in sheep fuels the idea that short chain fatty acids (SCFA) are instrumental in stimulating $\mathrm{Mg}$ absorption in ruminants. This notion is in line with the outcome of fundamental in-vitro research on $\mathrm{Mg}$ transport across the rumen epithelium.

The process of $\mathrm{Mg}$ uptake by rumen epithelial cells [20] consists of two components, one sensitive and one insensitive to K [21]. It was shown by Leonhard-Marek et al. [22] that SCFA can stimulate Mg absorption in-vitro with butyrate, relative to acetate and propionate, being most effective. These results prompted the authors $[22,23]$ to propose that a K-independent transporter was located at the apical membrane of the rumen epithelial cell, which exchanges one $\mathrm{Mg}$ ion for two hydrogen ions. It can, therefore, be speculated that $\mathrm{Mg}$ butyrate provided the protons to stimulate the K-independent transport across the apical membrane of the epithelial cells in the rumen. However, Schweigel and Martens [24] were not able to demonstrate a $\mathrm{Mg}^{2+} / 2 \mathrm{H}^{+}$exchanger in isolated rumen epithelium cells and these authors suggested the involvement of $\mathrm{H}^{+}$-ATPase activity to explain the 
butyrate induced stimulation in $\mathrm{Mg}$ transport across rumen epithelial cells. The involvement of $\mathrm{H}^{+}$-ATPase activity implicates that SCFA mediated $\mathrm{Mg}$ transport may also involve a voltage dependent pathway [24]. Clearly, the mechanism underlying the stimulatory effect of SCFA/butyrate on Mg absorption is not settled yet [25].

Magnesium transport across the basolateral membrane of rumen epithelial cells depends on a carrier mediated process based on the exchange of a $\mathrm{Mg}$ ion for two $\mathrm{Na}$ ions $[23,26]$. Thus, it can be speculated that the transport of $\mathrm{Mg}$ across the rumen epithelium can become saturated. Jittakhot et al. [6] however, reported that the apparent Mg absorption in dry cows, became saturated when a ration was fed containing $12 \mathrm{~g} \mathrm{Mg} / \mathrm{kg}$ dry matter. It can thus be speculated that the process of $\mathrm{Mg}$ absorption was not saturated in the current feeding experiment due to the rations containing a much lower amount of $\mathrm{Mg}$.

Despite the numerical increase in the urinary $\mathrm{Mg}$ concentration after the feeding of supplemental Mg-butyrate, the difference in the urinary $\mathrm{Mg}$ concentration did not reach statistical significance. This observation is not easy to explain because both DM intake and milk yield were found to be similar between the two experimental rations. It can be speculated that both $\mathrm{Mg}$ excretion with milk and the intake of electrolytes (i.e., $\mathrm{Na}$ and $\mathrm{K}$ ), was similar between the two rations. In view of the latter, the volume of urine produced is likely to have been similar between the two treatments. It seems, therefore, fair to assume that the lack of response in urinary $\mathrm{Mg}$ excretion cannot be explained by a difference in urine volume. Thus, the probability of type-1 error was most likely unfavorably affected by the high variation in the urinary $\mathrm{Mg}$ concentration.

\section{Conclusions}

$\mathrm{Mg}$-butyrate is a readily available $\mathrm{Mg}$ source and can be considered an attractive alternative to $\mathrm{MgO}$ to supplement dairy rations with $\mathrm{Mg}$.

Author Contributions: Conceptualization, J.E.E. and J.T.S.; methodology, J.T.S.; formal analysis, J.T.S.; investigation, B.M.G.; resources, J.T.S.; data curation, B.M.G.; writing-original draft preparation, J.T.S and B.M.G.; writing - review and editing, J.T.S, B.M.G., J.E.E.; visualization, B.M.G.; supervision, J.T.S..; project administration, J.T.S; funding acquisition, J.T.S.. All authors have read and agreed to the published version of the manuscript.

Funding: This research was funded by Utrecht University with partial financial support from Palital Feed Additives, Velddriel, The Netherlands.

Institutional Review Board Statement: The animal study protocol was approved by the Institutional Review Board of the Faculty of Veterinary Medicine, Utrecht University (approval number 10803-2020-05).

Acknowledgments: The authors thank the animal caretakers of the department of farm animal health for their technical assistance and excellent care of the cows.

\section{References}

Conflicts of Interest: The authors declare no conflict of interest.

1. Martens, H.; Schweigel, M. Pathophysiology of grass tetany and other hypomagnesemias: implications for clinical management. Vet Clin N Am-Food A 2000, 16, 339-368. DOI: 10.1016/s0749-0720(15)30109-2

2. Schonewille, J.T. Magnesium in dairy cow nutrition: an overview. Plant soil 2013, 368, 167-178. DOI: 10.1007/s11104-013-1665-5

3. Schonewille, J.T.; Van't Klooster; A.T.; Wouterse, H.; Beynen. A.C. Effects of intrinsic potassium in artificially dried grass and supplemental potassium bicarbonate on apparent magnesium absorption in dry cows. J Dairy Sci 1999, 82, 1824-1830. DOI: 10.3168/jds.S0022-0302(99)75413-5

4. Schonewille, J.T.; van 't Klooster, A.T.; Wouterse, H.; Beynen, A.C. Time courses of plasma magnesium concentrations and urinary magnesium excretion in cows subjected to acute changes in potassium intake. Vet Quart 2000, 22, 136-140. DOI: 10.1080/01652176.2000.9695042

5. Lean, I.J.; DeGaris, P.J.; McNeil, D.M.; Block, E. Hypocalcemia in dairy cows: meta-analysis and dietary cation anion difference theory revisited. J Dairy Sci 2006, 89, 669-684. DOI: 10.3168/jds.S0022-0302(06)72130-0

6. Jittakhot, S.; Schonewille, J.T.; Wouterse, H.; Uijttewaal, A.W.; Yuangklang, C.; Beynen, A.C. Increasing magnesium intakes in relation to magnesium absorption in dry cows. J Dairy Res 2004, 71, 297-303. DOI: https://doi.org/10.1017/S0022029904000275

7. Schonewille, J.T.; van't Klooster, A.T.; Van Mosel, M. A comparative study of the in-vitro solubility and availability of magnesium from various sources for cattle. Tijdschri Diergeneesk 1992, 117, 105-108. 
8. Xin, Z.; Tucker, W.B.; Hemken, R.W. Effect of reactivity rate and particle size of magnesium oxide on magnesium availability, acid-base balance, mineral metabolism, and milking performance of dairy cows. J Dairy Sci 1989, 72, 462-470. DOI: 10.3168/jds.S0022-0302(89)79128-1

9. Mentschel, J.; Leiser, R.; Mülling, C.; Pfarrer, C.; Claus, R. Butyric acid stimulates rumen mucosa development in the calf mainly by a reduction of apoptosis. Arch Anim Nutr 2001, 55, 85-102. DOI: 10.1080/17450390109386185

10. Malhi, M.; Gui, H.; Yao, L.; Aschenbach, J.R.; Gäbel, G.; Shen, Z. Increased papillae growth and enhanced short-chain fatty acid absorption in the rumen of goats are associated with transient increases in cyclin D1 expression after ruminal butyrate infusion. J Dairy Sci 2013, 96, 7603-7616. DOI: 10.3168/jds.2013-6700

11. Owens, F.N.; Secrist, D.S.; Hill, W.J.; Gill, D.R. Acidosis in cattle: a review. J Anim Sci 1998, 76, 275-286. DOI: $10.2527 / 1998.761275 x$

12. Goodlad, R.A. Some effects of diet on the mitotic index and the cell cycle of the ruminal epithelium of sheep. Q J Exp Physiol 1981, 66, 487-499. DOI: 10.1113/expphysiol.1981.sp002590

13. Odongo. N. E.; AlZahal. O.; Lindinger. M. I.; Duffield. T. F.; Valdes. E. V.; Terrell. S. P.; McBride. B. W. Effects of mild heat stress and grain challenge on acid-base balance and rumen tissue histology in lambs. J Anim Sci 2006, 84, 447-455.

14. International Organization for Standardization (ISO). Animal feeding stuffs - Determination of moisture and other volatile matter content. ISO 6496: 1999.

15. Myers, W.D.; Ludden, P.A.; Nayigihugu, V.; Hess, B.W. Excretion patterns of titanium dioxide and chromic oxide in duodenal digesta and feces of ewes. Small Ruminant Res 2008, 63, 135-141. DOI: 10.1016/j.smallrumres.2005.02.010

16. Schonewille, J.T.; Everts, H.; Jittakhot, S.; Beynen, A.C. Quantitative prediction of magnesium absorption in dairy cows. J Dairy Sci 2008, 91, 271-278. DOI: 10.3168/jds.2007-0304

17. Jesse, B.W.; Thomas, J.W.; Emery, R.S. Availability of magnesium from magnesium oxide particles of differing sizes and surfaces. J Dairy Sci 1981, 64, 197-205. DOI: 10.3168/jds.S0022-0302(81)82554-4

18. Ross, E.J.; Gibson, W.W.C. The effect of feeding a magnesium acetate molasses mixture on serum magnesium levels of dairy cows grazing spring pasture. Vet Rec 1969, 84, 520-525. DOI: 10.1136/vr.84.21.520

19. Giduck, S.A; Fontenot, J.P. Utilization of magnesium and other macrominerals in sheep supplemented with different readilyfermentable carbohydrates. J Anim Sci 1987, 65, 1667-1673. DOI: 10.2527/jas1987.6561667x

20. Tomas, F.M.; Potter, B.J. The site of magnesium absorption from the ruminant stomach. Brit J Nutr 1976, 36, 37-45. DOI: 10.1079/bjn19760056

21. Leonhard-Marek, S.; Martens, H. Effects of potassium on magnesium transport across rumen epithelium. Am J Physiol Gastrointestin Liver Physiol 1996, 271, G1034-G1038. DOI: 10.1152/ajpgi.1996.271.6.G1034

22. Leonhard-Marek, S.; Gäbel, G.; Martens, H. Effects of short chain fatty acids and carbon dioxide on magnesium transport across sheep rumen epithelium. Exp Physiol 1998, 83, 155-164. DOI: 10.1113/expphysiol.1998.sp004098

23. Leonhard-Marek, S.; Stumpff, F.; Martens, H. Transport of cations and anions across forestomach epithelia: conclusions from in vitro studies. Animal 2010, 4, 1037-1056. DOI: 10.1017/S1751731110000261

24. Schweigel, M.; Martens, H. Anion-dependent Mg2+ influx and a role for a vacuolar H+-ATPase in sheep ruminal epithelial cells. Am J Physiol Gastrointestin Liver Physiol 2003, 285, G45-G53. DOI: 10.1152/ajpgi.00396.2002

25. Martens, H.; Leonhard-Marek, S.; Rontgen, M.; Stumpff, F. Magnesium homeostasis in cattle: absorption and excretion. Nutr Res Rev 2018, 31, 114-130. DOI: 10.1017/S0954422417000257

26. Schweigel, M.; Vormann, J.; Martens, H. Mechanisms of Mg2+ transport in cultured ruminal epithelial cells. Am J Physiol Gastrointestin Liver Physiol 2000, 278, G400-G408. DOI: 10.1152/ajpgi.2000.278.3.G400 